\title{
Analysis of University Postgraduate Nursing Education in Spain
}

Joan Maria Estrada-Masllorens, PhD, RN; Eva Maria Guix-Comellas, MSc, RN, CNML; Sandra Cabrera-Jaime, PhD, RN; Jordi Galimany-Masclans, PhD, RN; Juan Roldan-Merino, PhD, RN; and Teresa Lluch-Canut, PhD, RN

\begin{abstract}
Background: The nursing education program framework in Spain has recently been adapted and modified, due to the implementation of the European Higher Education Area (EHEA), which provides standardization across European nursing education programs. This study aimed to analyze university postgraduate masters-level nursing education during the past 21 years in Spain in terms of educational supply and demand. The types of programs offered, in terms of specialty, define educational supply, and the types of educational programs sought by nurses define demand. This is important to determine the training needs of nurses and satisfy their requirements. Method: A retrospective, longitudinal, descriptive, and observational design was used. The educational offerings at 15 university nursing schools in Spain were examined. The target population was 7,871 registered and licensed nurses who had completed postgraduate education. The following data on trends in training were collected: type of educational facility, year the course was held, number of courses programmed, and geographical location. In terms of demand, the follow-
\end{abstract}

Received: November 24, 2015

Accepted: July 13, 2016

Dr. Estrada-Masllorens and Ms. Guix-Comellas are Professors, Department of Medical and Surgical Nursing, Dr. Galimany-Masclans and Dr. Lluch-Canut are Professors, Department of Public Health, Dr. Roldán-Merino is Professor, Sant Joan de Déu Nursing School, University of Barcelona [Query \#5: Should School of Nursing be added here, as it appears in the address for correspondence below?]; and Dr. Cabrera-Jaime is Research Methodology Consultant, Catalan Institute of Oncology, Barcelona, Spain.

The authors have disclosed no potential conflicts of interest, financial or otherwise.

Address correspondence to Eva Maria Guix-Comellas, MSc, RN, CNML, Professor, Department of Medical and Surgical Nursing, University of Barcelona School of Nursing, Campus de la Salut de Bellvitge, Edifici Pavello de Govern, Despatx 347, C/ Feixa Llarga s/n, 08907 L'Hospitalet de Llobregat, Spain; e-mail: evaguix@ub.edu.

doi:10.3928/01484834-2016xxxx-xx ing data were collected: age, gender, level of education, years of professional experience, hospital or primary care center, and unit or department. Results: Among the 211 programs offered, public universities' educational offerings were focused on two areas - public health (19 programs; 20.9\% of all offerings at public universities) and emergency care (9 programs; $15.7 \%$ ) - whereas most courses in private universities were in surgery (17 programs; $21.4 \%$ of offerings). Regarding demand, 1,235 nurses were enrolled. The most frequently requested educational areas were surgery, emergency and urgent care, and public health. The students' professional work environment influenced their choice of university $\left(\chi^{2}=6.596 ; p=.037\right)$; no statistically significant differences were found among the remaining variables. Conclusion: Although the postgraduate nursing education situation has changed, supply and demand for this type of education in Spain are well balanced at both public and private universities. Implementation of the EHEA in Spain brought with it increased competitiveness, which has prompted employers (hospitals, primary care centers, etc.) to demand nurses with a higher level of training. [Query \#1: JNE requires abstracts to be $\mathbf{1 5 0}$ words or fewer; please revise from 332 words to 150.] [J Nurs Educ. 2016;55(x):xxx-xxx.]

$\mathrm{P}$ ostgraduate education is key to improving the knowledge, skills, attitudes, and, ultimately, the competence of professional nurses. Both graduate and postgraduate masters-level education in nursing varies from country to country around the world in terms of duration, accreditation, degree nomenclature, and social recognition (Bellack, 2002). The legislation in each country and the nurses working there, with their leading associations, attempt to establish the best framework for nursing education amid the many and varied existing offerings. The range of courses offered is so great that in the United States alone, more than $600 \mathrm{RN}$-to-Bachelor of Science in Nursing (BSN) programs exist (McEwen, White, Pullis, \& Krawtz, 2012), and the number of students in these programs is growing rapidly (McEwen, Pullis, White, \& Krawtz, 2013). In 
Europe, the current situation of basic nursing education is different. Although demand is rising, the range of courses offered, while no more extensive than in the United States, is far more diverse due to educational differences and, until recently, lack of consensus between European countries. However, this situation has gradually improved in recent years, and changes made in nurse training have led, above all, to a considerable increase in the number and range of postgraduate and specialty programs offered (European Network of Nursing Organisations [ENNO], 2000; Zabalegui \& Cabrera, 2009).

\section{CHANGES IN EUROPEAN NURSING EDUCATION}

However, substantial differences previously existed among nursing education programs throughout Europe, with considerable variation in terms of structure, levels, and duration of degree studies (ENNO, 2000; Spitzer \& Perrenoud, 2006). With a view to standardizing nursing education among all the countries in the European Union (EU), in 1999, a regulation known as the Bologna Process was established through the European Higher Education Area (EHEA). The Bologna Process would, above all, standardize the accreditation of nursing education, thereby establishing and facilitating students' mobility from one university to another and allowing graduate nurses access to Doctor of Nursing programs (European Ministers of Education, 1999). This process ushered in a new educational structure consisting of three cycles: undergraduate level (basic), master's level (specialist nursing), and doctorate level (Öhlén, Furäker, Jakobson, Bergh, \& Hermansson, 2011).

Before the launch of the EHEA, initial basic educational offerings belonged to one of two broad groups: countries that imparted their education within the university framework and awarded university academic qualifications, including Spain, France (partial integration), Italy, Portugal, Norway, and Sweden, and countries that offered state-recognized qualifications regulated outside of university academic education, including Germany, Austria, Denmark, Luxembourg, and the Netherlands (European Commission of Education and Training, 1998). The age of access to studies was mainly between 17 and 18 years, and secondary education was a prerequisite. Some countries in southern Europe, as well as Austria, Denmark, England, and Sweden, further required passing an entrance examination.

Virtually all educational programs in the EU had a duration of 3 years (Davis, 2008), but some countries, such as Denmark, Finland, and Greece, extended their curriculum by 6 months, and in other countries, such as the Netherlands and Portugal, the courses lasted 4 years (National Agency of Quality Education Evaluation [ANECA], 2004). The number of hours of the training program ranged between 3,240 hours for the diplôme d'infirmière graduée (higher paramedic degree) in Belgium, and 6,720 hours for the Hoger Beroepsonderwijs (HBO) diploma in nursing in the Netherlands. The distribution of hours between theoretical and practical knowledge varied among countries and, in some cases, even among educational institutions within a single country. Even so, a trend toward an increase in theoretical education $(60 \%)$ versus clinical practice $(40 \%)$ was observed. After finalizing their education, most professionals could opt to complete specialization programs in different fields of the discipline (Millberg, Berg, Petzäll, \& Öhlen, 2011). Some countries offered these programs in a university setting; this was the case in Spain. Other countries, such as Luxembourg, developed them as specific programs with state-specific certificates and recognitions. Curricula were varied but included subjects focused on nursing care, fundamentals of nursing, and social sciences (ENNO, 2000).

The regulation established with the Bologna Process has led to the establishment of a basic university education with the qualification of a bachelor's degree in nursing, which, with subsequent specialist education, allows access to a doctoral program (Zabalegui et al., 2006).

\section{NURSING EDUCATION IN SPAIN}

In Spain, universities began to offer basic nursing education in 1977 as 3-year diploma programs (University Diploma in Nursing). University schools of nursing belonging to public and private universities were created (Law 11/1983, 1983; Mompart, 2004). With regard to postgraduate education, the process of developing nursing specialties has been slow and remains incomplete, and has been accompanied by great uncertainty as it has coincided with the application of the academic regulation for adaptation to the EHEA (De Pedro, 2005; Zabalegui \& Cabrera, 2009). Currently, nursing specialties are limited to midwifery, pediatric nursing, mental health nursing, family and community health nursing, geriatric nursing, occupational health nursing, and medical-surgical nursing (Royal Decree 450/2005). The first six have already been implemented, but not the last. As the specialty of medical-surgical nursing has yet to be introduced, nurses seeking to increase their knowledge in special areas in the field of medical-surgical nursing (which in Spain includes various specialist areas, such as emergency and urgent care, anesthesia, resuscitation, intensive care, palliative care, or prehospital care) or public health may pursue a specific university master's degree to obtain the qualification offered by each university that will allow them to work in that field. This is called university postgraduate education, by which they can obtain a master's degree that will enable them to become an advanced practice nurse. Although this master's degree is not recognized as an accredited specialty, it broadens these nurses' options in the labor market. It is also not considered to be continuing education because it is completed in a university setting under the accreditation of recognized Spanish universities.

Employers such as hospitals give preference to candidates holding a master's degree because they are considered to be better trained and prepared. However, a master's degree is no guarantee of a higher salary. Higher pay, or the opportunity to progress to a more specialized department in accordance with the master's specialty, will depend on the conditions prevailing in each hospital or primary care center.

A master's degree guarantees that the holder has more indepth, specialized knowledge, above all in advanced care practices, and is qualified to engage in research. In addition to technical skills, it shows that the nurse has also acquired nontechnical aptitudes, such as teamwork or leadership-competencies that will guarantee a higher quality of nursing care.

In this context, the authors posed the following questions: 
Does the current supply of educational programs meet the needs of nurses in terms of advancing their education from basic to specialty to doctorate? What postgraduate education programs do nurses complete throughout their professional lives, and over what time period? What motivates nurses to seek postgraduate specialist education?

\section{AIM}

The aim of this study was to analyze the situation of university postgraduate nursing education over a 21 -year period in Spain, particularly regarding (a) the past and current situations, (b) supply versus demand, (c) how many postgraduate education programs nurses completed throughout their professional lives, (d) time elapsed between basic education and postgraduate education, and (e) nurses' motivations in their choice of specialist education.

\section{METHOD}

\section{Study Design}

The study used a retrospective, longitudinal, descriptive, and observational design using mixed data collection techniques that included document analysis and an online questionnaire.

\section{Participants and Setting}

The target population included 7,871 registered and licensed nurses who had completed postgraduate education between the 1989-1990 and 2009-2010 academic years and who came from the 15 university nursing schools in the Spanish region of Catalonia. Four of the schools were publicly owned, and 11 were privately owned. The period chosen for the study spanned from the launch of the first postgraduate education program accredited by a Spanish university (1989) to the full implementation of the agreements for the creation of the EHEA (2010).

The nurses enrolled in the study (a) had pursued postgraduate education between the 1989-1990 and 2009-2010 academic years; (b) were male or female and of any age; (c) had any employment status; and (d) had granted their informed consent.

The exclusion criteria were (a) the questionnaire was partially or incorrectly filled out; (b) the presence of data inconsistent with official data of the education programs; and (c) professionals who had pursued a degree in another discipline after earning their diploma, with no other postgraduate education.

Participants were screened using nonprobability quota sampling. Coincidentally, all the professionals who voluntarily responded to the questionnaire sent were enrolled.

\section{Data Collected}

Regarding changes over time in university educational offerings, the following variables were examined: type of university school with educational offerings (public or private), year in which the educational offerings were available, total number of programs offered for each educational offering and educational field (e.g., management, critical care, geriatrics, oncology, etc.), and geographic location of the school.

Regarding demand, the following demographic variables were collected: age, gender, academic education, years of pro- fessional experience, work facility, and work unit. The number of programs completed, first and last education program pursued by each student, and motivation that led them to complete education programs were also collected.

\section{Procedure}

Data collection and fieldwork were completed in two stages according to the proposed study aims and using mixed techniques.

Data concerning postgraduate academic educational offerings in nursing at university institutions were collected retrospectively using a documentary review method. Secondary data taken from various documentary sources and databases at the 15 schools and institutions (i.e., leaflets promoting the programs, academic reports, and other periodical materials from the schools) were used. After the data were collected and analyzed, complementary and comparative data were gathered via interviews and direct interactions with 16 directors or heads of studies or those in charge of postgraduate education at the schools.

A three-part ad hoc questionnaire was prepared to collect data on educational demand and the professionals' work situations, as well as motivations for education. The first part gathered the professionals' sociodemographic and work data, and the other two parts gathered study variables concerning data on their first and last programs.

A consensus group of five professionals who were experts in the field of education created the questionnaire. A pilot test was conducted after the questionnaire was prepared and before it was used in the study. For the pilot test, an initial online questionnaire was sent to 35 former students from previous editions (i.e., the number of times a particular course has been given) of master's programs. Verification of optimal computer processing was followed by collection of all the suggestions made by the former students and the difficulties they reported experiencing while filling out the questionnaire, and those questionnaires were not included in the study.

The questionnaire was sent to a sample of 7,871 registered and licensed nurses who had completed postgraduate education; they were asked to complete them online using an access link.

Official colleges of nursing, nursing directorates, and heads of education and research at multiple hospitals and primary care facilities in Spain, as well as directors of the university nursing schools, were involved, and all collaborated in distributing the questionnaire online.

\section{Data Analysis}

The researchers subjected the data regarding educational offerings to descriptive analysis based on the documentation obtained in the form of reports, educational programs and curricula, lists of skills acquired in each course, informational flyers, and others. The most relevant information contained in these secondary sources was summarized and classified in two stages. First, the documents were formally analyzed to extract all elements relevant to the study variables. Following this, the content was analyzed, and the information was classified, indexed, and summarized with the help of representatives from the educational institutions (see the Procedure section of this article).

To study demand, the data were analyzed using descriptive 
TABLE 1

Distribution of the Courses and Editions Offered for Each Educational Area Between 1989 and 2010 in Public and Private University Nursing Schools

\begin{tabular}{|c|c|c|c|c|c|c|c|c|}
\hline \multirow[b]{3}{*}{ Educational Area } & \multicolumn{4}{|c|}{ Public University Schools } & \multicolumn{4}{|c|}{ Private University Schools } \\
\hline & \multicolumn{2}{|c|}{ No. of Courses } & \multicolumn{2}{|c|}{ No. of Editions } & \multicolumn{2}{|c|}{ No. of Courses } & \multicolumn{2}{|c|}{ No. of Editions } \\
\hline & $n$ & $\%$ & $n$ & $\%$ & $n$ & $\%$ & $n$ & $\%$ \\
\hline Management and administration & 10 & 9.5 & 34 & 6.7 & 9 & 8.5 & 42 & 6.7 \\
\hline Dietetics and nutrition & 6 & 5.7 & 6 & 1.2 & 2 & 1.9 & 21 & 3.4 \\
\hline Critical patient & 4 & 3.8 & 36 & 7.1 & 4 & 3.8 & 37 & 5.9 \\
\hline Chronic patient & 4 & 3.8 & 14 & 2.8 & 0 & 0 & 0 & 0 \\
\hline Medical patient & 7 & 6.7 & 34 & 6.7 & 7 & 6.6 & 51 & 8.1 \\
\hline Gerontology and geriatrics & 5 & 4.8 & 17 & 3.3 & 7 & 6.6 & 35 & 5.6 \\
\hline Research & 5 & 4.8 & 9 & 1.8 & 1 & 0.9 & 7 & 1.1 \\
\hline Neonatology and pediatrics & 6 & 5.7 & 33 & 6.5 & 7 & 6.6 & 55 & 8.8 \\
\hline Oncology and palliative care & 8 & 7.6 & 42 & 8.3 & 2 & 1.9 & 13 & 2.1 \\
\hline Other therapies & 2 & 1.9 & 4 & 0.8 & 10 & 9.4 & 35 & 5.6 \\
\hline Surgery & 8 & 7.6 & 40 & 7.9 & 17 & 16 & 134 & 21.4 \\
\hline Mental and psychosocial health & 5 & 4.8 & 28 & 5.5 & 5 & 4.7 & 31 & 5 \\
\hline Public and community health & 19 & 18.1 & 106 & 20.9 & 16 & 15.1 & 75 & 12 \\
\hline Emergency care & 9 & 8.6 & 80 & 15.7 & 10 & 9.4 & 69 & 11 \\
\hline Other & 7 & 6.7 & 25 & 4.9 & 9 & 8.5 & 21 & 3.4 \\
\hline Total & 105 & & 508 & & 106 & & 626 & \\
\hline
\end{tabular}

Note. Courses $=$ number of courses offered per educational area; Editions = the number of times a particular course has been given

statistics of central tendency and obtained by online query. They were extracted from the SQL database of the same online questionnaire system, then refined and processed for subsequent analysis using the Spanish version of the $\operatorname{SPSS}^{\odot}$ version 15.0 statistics software package for Windows. A univariate descriptive analysis was performed (calculating percentage, frequency, mean, standard deviation, median, and range, depending on whether they were qualitative or quantitative). A bivariate analysis was also performed (using a chi-square test and description with contingency tables, percentage, and number of cases for qualitative variables; and Student's $t$ test and ANOVA for inferential study of the relationship between the quantitative and qualitative variables, as well as mean and standard deviation). Wilcoxon's nonparametric test was applied to study paired samples to compare values between the first and last program. A $p$ value less than .05 was considered statistically significant.

\section{Ethical Considerations}

Institutional review board approval was obtained before the study was conducted. The participants granted their informed consent online if they were interested in participating, and all data were treated anonymously.

\section{RESULTS}

\section{Educational Offerings}

The educational offerings of 15 university nursing schools included 211 nursing-specific university postgraduate education programs during the 21-year period studied. Many of these programs were longstanding, and they had a combined total of 1,134 editions. After contributions from the group of experts were taken into account, the programs were grouped into 15 educational areas and were classified according to type of university (public or private). The postgraduate educational offerings in public universities were focused on two areas: public health (with 19 programs, 106 editions; 20.9\% of all offerings at public universities) and emergency care (9 programs, 80 editions; $15.7 \%$ ), whereas most courses in private universities were in surgery (with 17 programs, 134 editions; 21.4\%) (Table 1). Postgraduate educational offerings were initially more extensive at public universities, but this situation has changed and currently they are far more extensive at private universities (Figure). Regarding the format offered, on-site options $(97.7 \%)$ outnumbered hybrid and online options $(1.2 \%$ and $1.1 \%$, respectively).

\section{Educational Demand}

Sociodemographic Characteristics of the Sample. A total of 1,997 nurses responded to the survey, but following the refinement process, 762 questionnaires were removed because 
they had been filled out incorrectly. In the end, 1,235 nurses were enrolled; $91.9 \%(1,122)$ were women, with a mean age of 36.2 years ( $\mathrm{SD}=9.5$ years), with an age range of 22 to 63 years (Table 2). Most of them had completed their postgraduate education between the ages of 26 and 35 (ages 31-35 years: 22.5\% [ $n=277$ [Query \#2: Is $\boldsymbol{n}$ correct as added here and throughout?]]; ages 26-30 years: $21.8 \%[n=268]$ ), and only 10 nurses $(0.8 \%)$ had completed it when they were older than 60 years. The mean work experience for the professionals was 13.1 years $(S D=9.3$ years). The type of facility where they worked was public in $49 \%$ of cases $(n=602)$ and private in $51 \%(n=627)$. The distribution by field showed that $73.1 \%(n$ $=898$ ) of the professionals worked in a hospital setting, $21.2 \%$ $(n=260)$ worked in outpatient health facilities, and 5.7\% $(n=$ 70) worked in skilled nursing or rehabilitation facilities, businesses, or accident insurance companies. Five nurses (5.6\%) indicated that they were unemployed at the time of the study. All of them practiced in Spain, except for three $(0.24 \%)$ who practiced elsewhere.

Regarding the type of postgraduate education that they had completed, 95.6\% $(n=1,181)$ had postgraduate university education in nursing, $3.6 \%(n=44)$ had other non-nursing university degrees, and $0.8 \%(n=10)$ had a doctoral degree.

Description of the Educational Demand. Regarding demand, the most requested educational areas (in both the first program that the students completed and the last program where two or more programs were completed) were observed to be surgery ( $22 \%$ to $23.2 \%$ ), emergency and urgent care $(16.1 \%$ to $17.5 \%)$, and public health (15.2\% to $16.2 \%)$ (Table 3 ).

Potential determinants of students (age, field of work, work facility, and year in which postgraduate education was completed) were analyzed in relation to choice of university type. No statistically significant differences were found between the choice to be educated at a specific type of university and age $\left(\chi^{2}\right.$ $=6.654 ; p=.574)$; work facility, whether public or private $\left(\chi^{2}\right.$ $=5.890 ; p=.053)$; or year in which education was completed, whether it was the first program $\left(\chi^{2}=2.528 ; p=.470\right)$ or the last $\left(\chi^{2}=3.663 ; p=.300\right)$. By contrast, students' professional work environment influenced their choice of type of university $\left(\chi^{2}=\right.$ $6.596 ; p=.037$ ). More nurses working at outpatient health facilities completed their education at a public university $(19.8 \%)$ than a private one $(4.3 \%)$. Among nurses working in a hospital setting, $52.4 \%$ completed their education at a public university and $18.3 \%$ did so at a private one.

\section{University Postgraduate Education Programs Completed}

A single education program had been completed by $12.6 \%$ $(n=155)$ of the nurses, whereas two or more programs had been completed by $87.4 \%(n=1,080)$ (mean: $1.9 ; S D=1.2$ ). The time elapsed between the completion of the first and last program was 1 to 5 years in $61 \%$ of cases (6-10 years: $21.5 \%$; 11-15 years: $12.2 \%$; $16-10$ years: $5.4 \%$ ). The time dedicated to earning the qualification was an average of 340.5 hours $(S D=$ 319.3 hours; range: $100-3,000$ hours) for the first program and 762.9 hours $(S D=711.6$ hours; range $=120-4,500$ hours ) for the last.

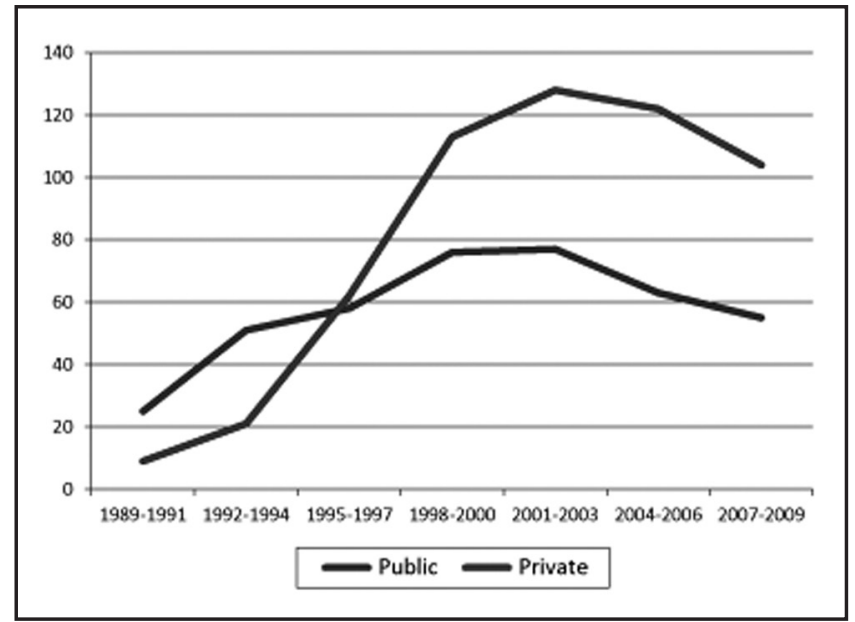

Figure. Number of postgraduate university courses offered between 1989 and 2010, according to the type of university nursing school. [Query \#6: Please revise the image so the lines for public and private are more distinguishable from one another, or otherwise explain which is which.]

\section{Time Elapsed Between Basic Education and Postgraduate Education}

Students who finished their basic university nursing studies more recently started their postgraduate education earlier. They waited an average of 1.5 years ( $S D=1.2$ years) [Query \#3: Please provide the $\boldsymbol{n}$.] to start this education, as opposed to 24.9 years $(S D=6.8$ years) for the 49 students who earned their diplomas before 1980 or 19.2 years $(S D=7.2$ years) for the 56 students who earned their diplomas between 1980 and 1984.

\section{Nurses' Motivations in Their Choice of University Postgraduate Education}

Students' motivations were analyzed according to whether the program in question was the first one they had completed or the last. No statistically significant differences were observed in any of the reasons for selecting an education program when the students had completed more than one program. The two main reasons were (a) to broaden their knowledge in new professional areas $(p=.700)$, with $35.5 \%$ (224 students) and $36.4 \%$ (230 students), respectively, depending on whether the program in question was the first they had completed or the last; and (b) broadening of knowledge in their same area of professional development $(p=.400)$, with $32.9 \%$ (208 students) and $35.2 \%$ (222 students), respectively.

An association was found between students motivated by broadening their knowledge in the area in which they already worked and completion of an education program at a private university, for both the first program $\left(\chi^{2}=13.867 ; p=.031\right)$ and the last $\left(\chi^{2}=12.650 ; p=.049\right)$. Professionals who practiced at public facilities were more motivated to be educated to earn points for future professional competitions or examinations when completing their first program $\left(\chi^{2}=28.048 ; p=.005\right)$, but not their last $\left(\chi^{2}=17.673 ; p=.126\right)$.

\section{DISCUSSION}


TABLE 2

Sociodemographic Data

\begin{tabular}{|c|c|c|c|}
\hline Variable & No. of Participants & $\%$ & $X(\delta)$ \\
\hline Gender & 1,235 & & \\
\hline Male & 113 & 8.1 & \\
\hline Female & 1,122 & 91.9 & \\
\hline Age (years) & 1,230 & & $36.2(9.5)$ \\
\hline$\leqslant 25$ & 138 & 11.2 & \\
\hline $26-30$ & 268 & 21.8 & \\
\hline $31-35$ & 277 & 22.5 & \\
\hline $36-40$ & 180 & 14.6 & \\
\hline $41-45$ & 123 & 10 & \\
\hline $46-50$ & 104 & 8.5 & \\
\hline $51-55$ & 101 & 8.2 & \\
\hline $56-60$ & 29 & 2.4 & \\
\hline$>60$ & 10 & 0.8 & \\
\hline Years of professional experience & 1,235 & & $13.1(9.3)$ \\
\hline Provider & 1,229 & & \\
\hline Public & 602 & 49 & \\
\hline Private & 627 & 51 & \\
\hline Care level & 1,228 & & \\
\hline Hospital & 898 & 73.1 & \\
\hline Primary & 260 & 21.2 & \\
\hline Other & 70 & 5.7 & \\
\hline Postgraduate training completed & 1,235 & & \\
\hline One course & 155 & 12.6 & \\
\hline Two or more courses & 1,080 & 87.4 & \\
\hline University & 1,235 & & \\
\hline Public & 936 & 75.8 & \\
\hline Private & 299 & 24.2 & \\
\hline
\end{tabular}

\& Krawtz, 2013; Zabalegui et al., 2006). This is arguably one of the reasons for the increase in supply and demand for postgraduate education, which is demonstrated by the current study and is among the main changes to have occurred in recent years. In this survey, current educational offerings of this type were more extensive at private universities, although it should be noted that the survey involved 11 private nursing schools and only four public ones.

The current study found a correlation between supply and demand for university postgraduate nursing education in Spain, but we were unable to determine which of two probable scenarios this balance should be attributed to: universities offering the master's programs that nurses need, or nurses themselves adapting to the choice of master's programs on offer. It is not always possible to strike a balance between supply and demand in nursing education, and it is not easy to maintain one. An imbalance is common. One example is the current situation in the United States, although (a) in the mid-1960s, prospective nurses were already being encouraged to

In the current study, the data reflected a change in the situation of university postgraduate nursing education in Spain, which has been adapted and modified in recent years, as has been described in theoretical terms by other authors (CamañoPuig \& Piqué-Angordans, 2008; Zabalegui \& Cabrera, 2009). Changes have also been significant in other countries, mainly in places where nursing is being pioneered as a profession, such as in the United States (Orsolini-Hain, \& Waters, 2009), Canada (Grenier \& Dewis, 1995), and the European Union in general (Zabalegui et al., 2006)—particularly the United Kingdom (Gould, Berridge, \& Kelly, 2006)—Denmark, Finland, Norway, Sweden (Råholm, Hedegaard, Löfmark, \& Slettebø, 2010; Pilhammar, 1999; Öhlén, Furäker, Jakobson, Bergh, \& Hermansson, 2011), and Hungary (Betlehem et al., 2008).

Currently, government agencies and official nursing associations in many countries have noted that the most qualified nurses will be in the highest demand (McEwen, Pullis, White, pursue mainly BSN degrees (American Nurses Association, 1965), (b) multiple groups and organizations intensified this insistence in the early 2000s, (c) the American Association of Colleges of Nursing (AACN) advocated for a bachelor's degree to become the minimum standard for RNs (AACN, 2012a), (d) the AACN argued that the more well-rounded education provided by a BSN makes nurses more versatile and better able to assume leadership roles and superior in their primary role of patient care (AACN, 2012b), and (e) many hospitals stipulate minimum levels of BSN-prepared RNs at the managerial level and this has heightened the preference for these BSNs. Despite all these considerations, demand for completing a BSN degree remains low compared with supply and existing need (McEwen, Pullis, White, \& Krawtz, 2013).

Demand for university postgraduate nursing education is on the rise, and, as such, graduate professionals are showing a growing interest in completing a master's degree or $\mathrm{PhD}$. 
Different studies have demonstrated this professional interest on the part of nurses in postgraduate education (Ballester et al., 2009). Therefore, it is important to analyze the motivations that lead them to complete these programs. In our study, nurses mainly sought to broaden their knowledge, whether in new professional areas or in the same professional area in which they were already working. This process-based motivation for broadening their knowledge or developing themselves is found in the same line in other international studies (Boore, 1996; Pelletier, Donoghue, Duffield, \& Adams, 1998; Zahran, 2013). In the current study, if nurses completed more than one program, their motivation to complete them had not changed from the first to the last. Therefore, university postgraduate nursing education programs may change, but these changes do not affect nurses' motivations for professional development. This may be something intrinsic to the profession; a look to the past confirms that this has historically been the case (Watson \& Wells, 1987).

\section{IMPLICATIONS FOR NURSING EDUCATION}

The broad situation shown in this study is significant for Spain, but could also have far-reaching implications for nursing education in other countries, such as the United States, where it can shed light on current university postgraduate education frameworks elsewhere. It is also important to note that nursing students, teachers, and researchers are moving around the world with increasing ease.

\section{CONCLUSION}

Following regulation through the EHEA, there have been many changes in Spain regarding university postgraduate nursing education: it is interesting to note that supply and demand for this type of education have increased yet remain well balanced at both public and private universities. Implementation of the EHEA in Spain brought with it increased competitiveness, a situation that has prompted employers (hospitals, primary care centers) to demand nurses with a higher level of training, particularly in areas where both supply and demand have increased. The educational areas most commonly offered
TABLE 3

rsity Postgraduate Courses Offered ${ }^{\mathrm{a}}$

\begin{tabular}{|c|c|c|c|}
\hline \multicolumn{2}{|c|}{$\begin{array}{l}\text { Educational Area of First } \\
\text { Postgraduate Course }\end{array}$} & \multicolumn{2}{|c|}{$\begin{array}{c}\text { Educational Area of Last } \\
\text { Postgraduate Course }\end{array}$} \\
\hline$n$ & $\%$ & $n$ & $\%$ \\
\hline 24 & 3.2 & 84 & 8.1 \\
\hline 17 & 2.2 & 14 & 1.3 \\
\hline 78 & 10.3 & 87 & 8.4 \\
\hline 19 & 2.5 & 61 & 5.9 \\
\hline 25 & 3.3 & 54 & 5.2 \\
\hline 24 & 3.2 & 17 & 1.6 \\
\hline 11 & 1.5 & 16 & 1.5 \\
\hline 56 & 7.4 & 43 & 4.1 \\
\hline 43 & 5.7 & 28 & 2.7 \\
\hline 24 & 3.2 & 17 & 1.6 \\
\hline 166 & 22 & 241 & 23.2 \\
\hline 28 & 3.7 & 21 & 2 \\
\hline 115 & 15.2 & 168 & 16.2 \\
\hline 122 & 16.1 & 182 & 17.5 \\
\hline 4 & 0.5 & 5 & 0.5 \\
\hline 756 & 100 & 1,038 & 100 \\
\hline
\end{tabular}

by universities were surgery, public health, and emergency care. The most commonly requested educational areas were surgery, emergency care, and public health, respectively.

Professionals who request this type of education are mainly motivated by a desire to increase their level of knowledge, whether in their areas of professional development or in other areas.

\section{REFERENCES}

American Association of Colleges of Nursing. (2012a). Fact sheet: Degree completion programs for registered nurses: $R N$ to master's degree and $R N$ to baccalaureate programs. Retrieved from http://www.aacn.nche. edu/media-relations/DegreeComp.pdf

American Association of Colleges of Nursing. (2012b). Fact sheet: The impact of education on nursing practice. Retrieved from http://www.aacn. nche.edu/media-relations/EdImpact.pdf

American Nurses Association. (1965). Education for nursing. American Journal of Nursing, 65, 106-111.

Ballester, A., Esteve, J., Guilera, A., Pérez, I., Ortega, O., \& Tarruella, M. (2009). Perfil y expectativas profesionales del estudiante de enfermería. Revista ROL de Enfermería, 32(7-8), 516-524. [Query \#4: Please provide the English translation.]

Bellack, J. (2002). A matter of degree. Journal of Nursing Education, 41, 191-192.

Boore, J.R. (1996). Postgraduate education in nursing: A case study. Journal of Advanced Nursing, 23, 620-629.

Camaño-Puig, R., \& Piqué-Angordans, J. (2008). Continuing education in the health sciences in Spain. The Journal of Continuing Education in Nursing, 39, 517-24. 
Davis, R. (2008). The Bologna process: The quiet revolution in nursing higher education. Nurse Education Today, 28, 935-942.

De Pedro, J. (2005). Las especialidades de enfermería [The nursing specialties]. Metas de Enfermería, 8(6), 50-54.

European Commission of Education and Training. (1998). Diploma supplement: Final report of the joint European Commission, Council of Europe and UNESCO/CEPES Working Party. Retrieved May 22, 2015, from http//Europe.eu.int/comm/educaron/recognition/index.html

European Ministers of Education. (1999). Bologna declaration. The European Higher Education Area, Bologna: The National Unions of Students in Europe. Retrieved May 22, 2015, from http//www.esib.org/ $\mathrm{BPC} /$ docs/Archives/CoP007bolognadeclaration.pdf

European Network of Nursing Organisations. (2000). Recommendations for a European framework for specialist nursing education. Retrieved June 9, 2014, from http://www.esgena.org/assets/downloads/pdfs/general/ enno_framework.pdf

Gould, D., Berridge, E.J., \& Kelly, D. (2006). The National Health Service Knowledge and Skills Framework and its implications for continuing professional development in nursing. Nurse Education Today, 27, 2634. doi:10.1016/j.net.2006.02.006

Grenier, F., \& Dewis, E. (1995) The baccalaureate degree as entry to practice: A Canadian model of educational collaboration toward the goal. Journal of Nursing Education, 34, 87-88.

Law 11/1983, August 25. Law of University Reform. State Official Bulletin, No. 209. (September 1, 1983).

McEwen, M., Pullis, B.R., White, M.J., \& Krawtz, S. (2013). Eighty percent by 2020: The present and future of RN-to-BSN education. Journal of Nursing Education, 52, 549-557.

McEwen, M., White, M.J., Pullis, B.R., \& Krawtz, S. (2012). National survey of RN-to-BSN programs. Journal of Nursing Education, 51, 373380.

Millberg, L., Berg, L., Petzäll, K., \& Öhlen, J. (2011). Tensions related to implementation of postgraduate degree projects in specialist nursing education. Nurse Education Today, 31, 283-288.

Mompart, M.P. (2004). Rebelión en las aulas: de las escuelas de ATS a las Universitarias de Enfermería [Rebellion in the Classrooms in the Schools for Technical Nursing Assistants in University Nursing Depart- ments]. Revista ROL de Enfermería, 27(10), 6-16.

Nacional Agency of Quality Education Evaluation. (2004). Libro blanco: Título de grado de enfermería [White book of nursing degree]. Retrieved April 23, 2014, from http://www.um.es/c/document_library/get_ file?uuid=56fb9094-e5b8-4d3a-ace5-d7905d85e4c4\&groupId=479763

Öhlén, J., Furäker, C., Jakobson, E., Bergh, I., \& Hermansson, E. (2011). Impact of the Bologna process in bachelor nursing programmes: The Swedish case. Nurse Education Today, 31, 122-128.

Orsolini-Hain, L., \& Waters, V. (2009). Education evolution: A historical perspective of associate degree nursing. Journal of Nursing Education, 48, 266-271.

Pelletier, D., Donoghue, J., Duffield, C., \& Adams, A. (1998) Nurses' perceptions of their professional growth on completion of two years of postgraduate education. Australian Journal of Advanced Nursing, 16(2), 26-35.

Pilhammar, E. (1999). From vocational training to academic education: The situation of the schools of nursing in Sweden. Journal of Nursing Education, 38, 33-38.

Råholm, M., Hedegaard, B.L., Löfmark, A., \& Sletteb $\varnothing$, Å. (2010). Nursing education in Denmark, Finland, Norway, and Sweden-From bachelor's degree to PhD. Journal of Advanced Nursing, 66, 2126-2137.

Royal Decree 450/2005, 22/04/2005. Nursing specialities, BOE No. 108.

Spitzer, A., \& Perrenoud, B. (2006). Reforms in nursing education across Western Europe: Implementation processes and current status. Journal of Professional Nursing, 22, 162-171.

Watson, P.G., \& Wells, N. (1987) Nurses' attitudes toward the advantages of master's degree preparation in nursing. Journal of Nursing Education, 26, 63-68

Zabalegui, A., \& Cabrera, E., (2009). New nursing education structure in Spain. Nurse Education Today, 29, 500-504.

Zabalegui, A., Macia, L., Márquez, J., Ricomá, R., Nuin, C., Mariscal, I., .. . Moncho, J. (2006). Changes in nursing education in the European Union. Journal of Nursing Scholarship, 38, 114-118.

Zahran, Z. (2013) Master's level education in Jordan: A qualitative study of key motivational factors and perceived impact on practice. Nurse Education Today, 33, 1051-1056. 